Majumdar, A., \& Hosur, R. V. (1990) J. Magn. Reson. 88, 284-304.

Mastrangelo, D., Mathison, R., Huggel, M. J., Dion, S., D'Orleans-Juste, P., Rhaleb, N. E., Drapeau, G., Rovero, P., \& Regoli, D. (1986) Eur. J. Pharmacol. 134, 321-326.

Motta, A., Picone, D., Tancredi, T., \& Temussi, P. A. (1987) J. Magn. Reson. 75, 364-370.

Motta, A., Picone, D., Tancredi, T., \& Temussi, P. A. (1988) Tetrahedron 44, 975-990.

Narita, M., Doi, M., Kudo, K., \& Terauchi, Y. (1986) Bull. Chem. Soc. Jpn. 59, 3553-3557.

Nawa, H., Hirose, T., Takashima, H., Inayama, S., \& Nakanishi, S. (1983) Nature (London) 306, 32-36.

Nawa, H., Doteuchi, M., Igano, K., Inouye, K., \& Nakanishi, S. (1984) Life Sci. 34, 1153-1160.

Piantini, U., Sørensen, O. W., \& Ernst, R. R. (1982) J. Am. Chem. Soc. 104, 6800-6801.

Rovero, P., Pestellini, V., Patacchini, R., Santicioli, P., Maggi, C. A., \& Meli, A. (1987) Neuropeptides 10, 355-359.
Rovero, P., Pestellini, V., Rhaleb, N. E., Dion, S., Rouissi, N., Tousignant, C., Telemaque, S., Drapeau, G., \& Regoli, D. (1989a) Neuropeptides 13, 263-270.

Rovero, P., Pestellini, V. Patacchini, R., Giuliani, S., Santicioli, P., Maggi, C. A., Meli, A., \& Giachetti, A. (1989b) Peptides 10, 593-595.

Salunke, D. M., \& Vijayan, M. (1984) Biochim. Biophys. Acta 798, 180-186.

Schwyzer, R. (1987) in Peptides 1986 (Theodoropoulos, D., Ed.) pp 7-23, Walter de Gruyter, Berlin and New York. Shanno, D. F. (1970) Math. Comput. 24, 647-655.

Sumner, S. C. J., \& Ferretti, J. A. (1989) FEBS Lett. 253, 117-120.

Temussi, P. A., Picone, D., Castiglione-Morelli, M. A., Motta, A., \& Tancredi, T. (1989) Biopolymers 28, 91-107.

Weiner, S. J., Kollman, P. A., Nguyen, D. T., \& Case, D. A. (1986) J. Comput. Chem. 7, 230-237.

Wüthrich, K. (1976) NMR in Biological Research: Peptides and Proteins, North-Holland Publishing Co., Amsterdam.

\title{
A cAMP-Binding Ectoprotein in the Yeast Saccharomyces cerevisiae ${ }^{\dagger}$
}

\author{
Günter Müller, ${ }^{*,+\&}$ and Wolfhard Bandlowll \\ Institut für Biochemie I der Universität Heidelberg, Im Neuenheimer Feld 328, D-6900 Heidelberg l, \\ Federal Republic of Germany, and Institut für Genetik und Mikrobiologie der Universität München, Maria-Ward-Strasse la, \\ D-8000 München 19, Federal Republic of Germany
}

Received February 12, 1991; Revised Manuscript Received May 14, 1991

\begin{abstract}
Purified plasma membranes from the yeast Saccharomyces cerevisiae bind about 1.2 pmol of $\mathrm{cAMP} / \mathrm{mg}$ of protein with high affinity $\left(K_{\mathrm{d}}=6 \mathrm{nM}\right)$. By using photoaffinity labeling with 8- $\mathrm{N}_{3}-\left[{ }^{32} \mathrm{P}\right] \mathrm{cAMP}$, we have identified in plasma membrane vesicles a cAMP-binding protein $\left(M_{\mathrm{r}}=54000\right)$ that is present also in $b c y l$ disruption mutants, lacking the cytoplasmic $\mathrm{R}$ subunit of protein kinase A (PKA). This argues that it is genetically unrelated to PKA. Neither high salt, nor alkaline carbonate, nor cAMP extract the protein from the membrane, suggesting that it is not peripherally bound. The observation that (glycosyl)phosphatidylinositol-specific phospholipases (or nitrous acid) release the amphiphilic protein from the membrane, thereby converting it to a hydrophilic form, indicates anchorage by a glycolipidic membrane anchor. Treatment with $\mathrm{N}$-glycanase reduces the $M_{\mathrm{r}}$ to $44000-46000$ indicative of a modification by $\mathrm{N}$-linked carbohydrate side chain(s). In addition to the action of a phospholipase, the efficient release from the membrane requires the removal of the carbohydrate side chain(s) or the presence of high salt or methyl $\alpha$-mannopyranoside, suggesting complex interactions with the membrane involving not only the glycolipidic anchor but also the glycan side chain(s). Topological studies show that the protein is exposed to the periplasmic space, raising intriguing questions for the function of this protein.
\end{abstract}

$\mathbf{I}$

In the yeast Saccharomyces cerevisiae, cAMP1 is known to influence a number of cellular processes and to link them to the nutritional situation of the cell. Among them are storage carbohydrate metabolism (Pall, 1981; Thorner, 1982), cell size regulation and cell cycle progression (Matsumoto et al., 1985; Baroni et al., 1989), sporulation (Matsumoto et al., 1983a,b), and transcription (Merino et al., 1989). Control of these functions is thought to be achieved through the activation of

\footnotetext{
${ }^{\dagger}$ This work was, in part, supported by a grant to W.B. from the Deutsche Forschungsgemeinschaft.

tInstitut für Biochemie I der Universität Heidelberg.

1 Present address: Hoechst AG Frankfurt a.M., Pharmaceutical Research Division, Metabolism, P.O. Box 8003 20, D-6230 Frankfurt am Main 80, Federal Republic of Germany.

"Institut für Genetik und Mikrobiologie der Universität München.
}

the well-characterized cytoplasmic cAMP-dependent protein kinases (Beebe \& Corbin, 1986) in response to the modulation

\footnotetext{
${ }^{1}$ Abbreviations: cAMP, adenosine 3',5'-cyclic monophosphate; C (R) subunit, catalytic (regulatory) subunit; DTT, dithiothreitol; EDTA, ethylendiaminetetraacetic acid; EGTA, ethylene glycol bis( $\beta$-aminoethyl ether)- $N, N, N^{\prime}, N^{\prime}$-tetraacetic acid; GPI, glycosylphosphatidylinositol; HEPES, $N$-(2-hydroxyethyl)piperazine- $N^{\prime}-2$-ethanesulfonic acid; IBMX, 3-isobutyl-1-methylxanthine; MES, 2-( $N$-morpholino)-ethanesulfonic acid; $\alpha$-MMP, methyl $\alpha$-mannopyranoside; MOPS, 3-( $N$-morpholino)propanesulfonic acid; $\mathrm{N}$-glycanase, peptide $\mathrm{N}$-glycohydrolase F; PEG, poly(ethylene glycol); (G)PI-PLC (D), (glycosyl)phosphatidylinositolspecific phospholipase C (D); PKA, cAMP-dependent protein kinase; PMSF, phenylmethanesulfonyl fluoride; SDS-PAGE, sodium dodecyl sulfate-polyacrylamide gel electrophoresis; TCA, trichloroacetic acid; Tris, tris(hydroxymethyl)aminomethane; TX-114, Triton X-114, poly(ethylene glycol) mono(octyl phenyl ether).
} 
of the intracellular cAMP concentration (Matsumoto et al., 1982a; Uno et al., 1982). cAMP-dependent protein kinases (PKA's) are heterotetrameric in yeast and in most other organisms, built up from two regulatory, cAMP-binding (R) and two catalytic (C) subunits (Edelman et al., 1987). The binding of cAMP to $\mathrm{R}$ effects the dissociation of the complex, resulting in the release of two active $C$ subunits. This type of protein kinase A usually occurs in the cytoplasm but has also been observed associated with the cytoplasmic faces of a variety of intracellular membranes (Nigam \& Blobel, 1989; Nigg et al., 1985a,b) including plasma membranes (Behrens \& Mazon, 1988). Since the constituent $R$ and $C$ subunits lack obvious transmembrane domains, the binding to the various membranes appears to be mediated by protein-protein interactions. Alternatively, posttranslational modifications, e.g., acylation with long chain fatty acids, of proteins have been attributed a functional role in their association with membranes (Olson \& Spitz, 1986; Rhee \& Hunter, 1987).

A new type of cAMP-dependent protein kinase has been found recently in mitochondria embedded in the organelle's inner membrane (Rödel et al., 1985; Müller \& Bandlow, 1987). Its membrane association is due neither to ionic protein-protein interactions nor to a proteinaceous transmembrane domain but is due to anchorage of the cAMP-binding protein by a lipid structure containing phosphatidylinositol lacking carbohydrate (Müller \& Bandlow, 1989b).

Here we describe a similar cAMP-binding protein in plasma membranes from yeast. It shares the property with the mitochondrial counterpart that it is bound to the membrane by a lipid-containing structure that can be cleaved by GPI-specific phospholipases. It differs from the mitochondrial isoprotein in molecular weight, being larger mainly due to $\mathrm{N}$ glycosylation. We present also strong evidence that this cAMP-binding protein is different from the $\mathrm{R}$ subunit of the cytoplasmic PKA and is oriented toward the extracellular space.

\section{Materials and Methods}

Materials were obtained as follows: $N-\left[{ }^{3} \mathrm{H}\right]$ acetyl concanavalin $\mathrm{A}$ (45 $\mathrm{Ci} / \mathrm{mmol}$ ) from Amersham-Buchler, Braunschweig; 8- $\mathrm{N}_{3}-\left[{ }^{32} \mathrm{P}\right]$ cAMP $(20 \mathrm{Ci} / \mathrm{mmol})$ from ICN, Eschwege; concanavalin A-Sepharose and Percoll from Phar-

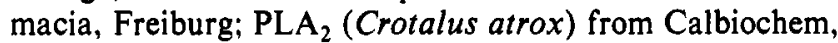
La Jolla, CA; PI-PLC (Bacillus cereus) and N-glycanase (Flavobacterium menigosepticum) from Boehringer, Mannheim. GPI-PLD from rabbit serum was a donation from $W$. Gutensohn, München; GPI-PLC from Trypanosoma brucei was the gift of P. Overath, Tübingen. Mixed ester cellulosic filters were purchased from Millipore, Eschborn; cAMP, $\alpha$-MMP, and PEG 4000 were from Sigma, Deisenhofen, all other chemicals were obtained as described (Müller \& Bandlow, 1989a).

Yeast Strains, Cell Growth, and Subcellular Fractionation. Cells from the haploid protease-deficient strain ABYS1 $M A T$ pral-1 prb1-1 prc1-1 cps1-3 ade lacking the vacuolar proteinases $A$ and $B$ and carboxypeptidases $Y$ and $S$ (Achstetter et al., 1984) and from the bcyl disruption mutant EG273-5A $M A T \alpha$ leu 2 ura3 his 4 ade2-1 bcyl::HIS3 (Cannon \& Tatchell, 1987) were grown at $30^{\circ} \mathrm{C}$ to log phase in lactate medium as described (Müller \& Bandlow, 1989a). Cellular subfractions were isolated from spheroplasts (Rödel et al., 1985). All subsequent experimental steps were performed in the presence of a cocktail of protease inhibitors (Müller \& Bandlow, 1989a). The cell lysate was centrifuged (1000g, 3 $\left.\min , 4^{\circ} \mathrm{C}\right)$, the pellet was washed with SEM buffer $(0.25 \mathrm{M}$ sucrose, $0.5 \mathrm{mM}$ EDTA, $20 \mathrm{mM}$ MOPS/KOH, pH 7.4) and recentrifuged two times, and the combined supernatants were adjusted to $28 \%$ Percoll in SEM buffer $(0.5 \mathrm{mg}$ of protein $/ \mathrm{mL})$ and centrifuged $\left(18000 \mathrm{~g}, 15 \mathrm{~min}, 4^{\circ} \mathrm{C}\right.$, fixed angle rotor).

The cytoplasmic supernatant on top of the gradient was cleared by centrifugation $\left(300000 \mathrm{~g}, 60 \mathrm{~min}, 4^{\circ} \mathrm{C}\right)$ and precipitated by $15 \%$ PEG $6000(48000 \mathrm{~g}, 30 \mathrm{~min})$, washed, and finally dissolved in $25 \mathrm{mM}$ Tris- $\mathrm{HCl}$ (pH 7.0), $1 \mathrm{mM}$ EDTA at $4 \mathrm{mg} / \mathrm{mL}$. The band just below the top of the gradient (plasma membranes, $3 \mathrm{~mL}$ ) was diluted with 5 volumes of SEM buffer and spun down $\left(48000 \mathrm{~g}, 30 \mathrm{~min}, 4^{\circ} \mathrm{C}\right)$. The pellet was resuspended in MOPS buffer at $5 \mathrm{mg} / \mathrm{mL}$ and incubated in portions of $1 \mathrm{mg}$ of protein with $55 \mu \mathrm{Ci}$ of $N$ $\left[{ }^{3} \mathrm{H}\right]$ acetyl concanavalin $\mathrm{A}$ in a total volume of $500 \mu \mathrm{L}$ of MOPS buffer (20 mM MOPS/KOH, pH 7.4, $0.5 \mathrm{mM}$ EDTA, $50 \mathrm{mM} \mathrm{KCl}, 5 \mathrm{mM} \mathrm{CaCl}, 200 \mu \mathrm{g}$ of BSA) under mild ultrasonic treatment in a water bath sonifier for $60 \mathrm{~min}$ at $4{ }^{\circ} \mathrm{C}$. The suspension was layered on top of a continuous sucrose gradient (15-28\% sucrose in MOPS buffer) and centrifuged $\left(25000 \mathrm{rpm}, 90 \mathrm{~min}, 4^{\circ} \mathrm{C}\right.$, Beckman SW27 rotor), and the gradients were fractionated from the bottom $(0.6-\mathrm{mL}$ portions), and aliquots were counted for radioactivity. Peak fractions (23\% sucrose) were diluted 3-fold with MOPS buffer containing $50 \mathrm{mM}$ concanavalin $\mathrm{A}$ and $250 \mathrm{mM} \mathrm{KCl}$ and spun down $\left(200000 \mathrm{~g}, 60 \mathrm{~min}, 4^{\circ} \mathrm{C}\right.$, Beckman TL-100, fixed angle rotor). The pellet was washed and recentrifuged two times with SEM buffer containing $250 \mathrm{mM} \mathrm{KCl}$ and once with SEM buffer lacking $\mathrm{KCl}$ and finally suspended in SEM buffer at $2.5 \mathrm{mg}$ of protein $/ \mathrm{mL}$.

Microsomes were recovered from the middle band of the above Percoll gradient (1.5 mL), diluted 3-fold with MOPS buffer containing $150 \mathrm{mM} \mathrm{KCl}$, and centrifuged $(100000 \mathrm{rpm}$, $4^{\circ} \mathrm{C}, 60 \mathrm{~min}$, Beckman TL-100, fixed angle rotor). The pellet was resuspended in the same buffer containing $0.25 \mathrm{M}$ sucrose at $0.5 \mathrm{mg} / \mathrm{mL}$, layered on top of a $0.5 \mathrm{M}$ sucrose cushion in the same buffer, and centrifuged $\left(40000 \mathrm{rpm}, 90 \mathrm{~min}, 4^{\circ} \mathrm{C}\right.$, Beckman TL-100, swing out rotor). The final pellet was resuspended in $0.1 \mathrm{M}$ sucrose $/ 20 \mathrm{mM}$ MOPS ( $\mathrm{pH} 7.2) / 0.5$ mM EDTA $(1.5 \mathrm{mg} / \mathrm{mL})$.

Mitochondria were prepared from the lower band in the lower one-third of the above Percoll gradient $(1.5 \mathrm{~mL})$, diluted with 10 volumes of SEM buffer, and centrifuged $(20000 \mathrm{~g}, 30$ $\left.\min , 4^{\circ} \mathrm{C}\right)$. The pellet was suspended in SEM buffer ( 5 $\mathrm{mg} / \mathrm{mL}$ ), layered on top of a $2.5-\mathrm{mL}$ (per milligram of protein) cushion of $28 \%$ Percoll in SEM buffer, and further centrifuged and processed as described previously (Müller \& Bandlow, $1989 \mathrm{a}$ ). Aliquots of subcellular fractions were frozen in liquid nitrogen and stored at $-70^{\circ} \mathrm{C}$.

Separation of Inside Out and Outside Out Plasma Membrane Vesicles. Diluted (125 $\mu \mathrm{g}$ of protein $/ \mathrm{mL}$, with 20 volumes of $20 \mathrm{mM}$ MOPS, pH 7.2/0.5 mM EDTA) and sonicated ( 10 pulses of $15 \mathrm{~s}$ each, Branson waterbath sonifier at maximum intensity) plasma membrane vesicles were spun down $\left(200000 \mathrm{~g}, 60 \mathrm{~min}, 4^{\circ} \mathrm{C}\right)$ and resuspended in SEM buffer ( $1 \mathrm{mg} / \mathrm{mL}$ ) containing $1 \mu \mathrm{g} / \mathrm{mL}$ bacitracin, $20 \mu \mathrm{g} / \mathrm{mL}$ PMSF, $2 \mathrm{mM} \mathrm{MgCl}, 5 \mathrm{mM} \mathrm{CaCl}_{2}, 75 \mathrm{mM} \mathrm{KCl}$, and $10 \%$ glycerol. The suspension was mixed batchwise with $5 \mathrm{~mL}$ of concanavalin A-Sepharose $(15 \mathrm{mg} / \mathrm{mL})$ in the same buffer (bacitracin omitted) and left on ice for $30 \mathrm{~min}$ under stirring to allow agglutination. The suspension was then filled into a column. Inside out vesicles were washed from the column with 2 volumes of the same buffer and centrifuged through a cushion of $5 \mathrm{~mL}$ of $0.5 \mathrm{M}$ sucrose in $25 \mathrm{mM}$ MOPS/KOH $(\mathrm{pH} \mathrm{7.4)/1}$ $\mathrm{mM}$ EDTA $/ 75 \mathrm{mM} \mathrm{KCl} / 20 \mu \mathrm{g} / \mathrm{mL}$ PMSF $(100000 \mathrm{~g}, 60$ min, $4^{\circ} \mathrm{C}$, Beckman TL-100, swing out rotor). The pellet (inside out vesicles) was washed twice with SEM buffer and 
suspended in the same buffer at $2 \mathrm{mg} / \mathrm{mL}$. Outside out vesicles were subsequently eluted with 5 volumes of $0.1 \mathrm{M}$ $\alpha$-MMP in $50 \mathrm{mM}$ MOPS/KOH (pH 7.4)/0.2 mM EDTA containing $250 \mathrm{mM} \mathrm{KCl}, 10 \%$ glycerol, $1 \mu \mathrm{g} / \mathrm{mL}$ bacitracin, and $20 \mu \mathrm{g} / \mathrm{mL}$ PMSF. Protein-containing fractions $(0.5 \mathrm{~mL})$ were pooled and centrifuged as described above.

Phospholipase Treatments. A total of $75 \mu \mathrm{g}$ of mitochondrial or plasma membranes or $150 \mu \mathrm{g}$ of spheroplasts, photoaffinity labeled with $8-\mathrm{N}_{3}-\left[{ }^{32} \mathrm{P}\right] \mathrm{cAMP}$ (approximately $100000 \mathrm{cpm}$ ), was pelleted $(100000 \mathrm{~g}, 30 \mathrm{~min}$, or $5000 \mathrm{~g}, 5 \mathrm{~min}$, respectively) and washed in the respective incubation buffers. For PLA $\mathrm{A}_{2}$ treatment, the membranes were suspended in 500 $\mu \mathrm{L}$ of $0.5 \mathrm{M}$ Tris- $\mathrm{HCl}(\mathrm{pH} 7.5) / 0.25 \mathrm{M}$ sucrose/ $15 \mathrm{mM}$ $\mathrm{CaCl}_{2}$ containing $0.5 \% \mathrm{TX}-100$. A total of $50 \mu \mathrm{L}$ of $\mathrm{PLA}_{2}$ solution $(15 \mathrm{mg} / \mathrm{mL})$ was added and the mixture incubated for $1 \mathrm{~h}$ at $37^{\circ} \mathrm{C}$. For PI-PLC (B. cereus) treatment, the membranes were resuspended in $500 \mu \mathrm{L}$ of HEPES/NaOH buffer $(\mathrm{pH} 7.4) / 0.25 \mathrm{M}$ sucrose. For solubilization $0.1 \%(\mathrm{w} / \mathrm{v})$ sodium deoxycholate was added and the supernatant of a centrifugation $\left(150000 \mathrm{~g}, 60 \mathrm{~min}, 4^{\circ} \mathrm{C}\right)$ was used for the digestion. A total of $25 \mu \mathrm{L}$ of a PI-PLC stock solution (about $2.5 \mu \mathrm{g}$ of enzyme) was added, and the mixtures were incubated for $1 \mathrm{~h}$ at $37^{\circ} \mathrm{C}$. For treatment with GPI-PLC (T. brucei) the membranes were suspended in $500 \mu \mathrm{L}$ of $10 \mathrm{mM}$ Tris-HCl (pH 8.0) $/ 0.25 \mathrm{M}$ sucrose $/ 150 \mathrm{mM} \mathrm{NaCl}$. A total of $10 \mu \mathrm{L}$ of trypanosomal PLC ( 0.5 unit) was added, and the mixture was incubated for $30 \mathrm{~min}$ at $30^{\circ} \mathrm{C}$. For GPI-PLD treatment the membranes were suspended in $500 \mu \mathrm{L}$ of $20 \mathrm{mM}$ potassium phosphate (pH 5.6)/0.25 M sucrose $/ 75 \mathrm{mM} \mathrm{CaCl}_{2}, 50 \mu \mathrm{g}$ of GPI-PLD was added, and the mixture incubated for $90 \mathrm{~min}$ at $37^{\circ} \mathrm{C}$. The incubations were terminated by the addition of $2 \mathrm{mM}$ EGTA/1 mM EDTA and separation into soluble and membrane-associated proteins by centrifugation $(150000 \mathrm{~g}$, $60 \mathrm{~min}, 4^{\circ} \mathrm{C}$ ) or into hydrophilic and amphiphilic proteins by TX-114 partitioning.

$N$-Glycanase Treatment. A total of $100000 \mathrm{cpm}$ of 8$\mathrm{N}_{3}-\left[{ }^{32} \mathrm{P}\right]$ cAMP photoaffinity-labeled mitochondrial or plasma membranes was dissolved in $0.1 \mathrm{M}$ sodium phosphate buffer (pH 8.6)/0.25 M sucrose/ $10 \mathrm{mM}$ 1,10-phenanthroline/5 mM DTT $/ 0.1 \%$ SDS. The supernatant of a centrifugation $\left(150000 \mathrm{~g}, 30 \mathrm{~min}, 4^{\circ} \mathrm{C}\right)$ was then incubated with $\mathrm{N}$-glycanase (with 2.5 units for $18 \mathrm{~h}$ at $37^{\circ} \mathrm{C}$ ) in the presence of $0.01 \%$ SDS. The digestions were terminated by the addition of acetone $/ 0.07 \mathrm{M} \mathrm{HCl}$ followed by centrifugation at $12000 \mathrm{~g}$ for $10 \mathrm{~min}$. Precipitates were washed successively with acetone, $0.07 \mathrm{M} \mathrm{HCl}$, and ether and dried. The protein was dissolved in $25 \mu \mathrm{L}$ of $50 \mathrm{mM}$ Tris- $\mathrm{HCl}$ ( $\mathrm{pH} \mathrm{6.8),} \mathrm{containing} \mathrm{1 \%} \mathrm{SDS,}$ $5 \mathrm{mM}$ EDTA, and $1 \mathrm{mM} \beta$-mercaptoethanol, boiled for $5 \mathrm{~min}$, and analyzed by SDS-PAGE.

Photoaffinity-labeled sealed (1.5 $\mathrm{M}$ sorbitol) or detergent-solubilized $(0.5 \%$ MEGA 10$)$ yeast spheroplasts or homogenate was incubated at $0.5 \mathrm{mg} / \mathrm{mL}$ in $0.1 \mathrm{M}$ phosphate buffer (pH 8.6) $/ 5 \mathrm{mM} \mathrm{DTT} / 10 \mathrm{mM}$ 1,10-phenanthroline with 25 units $/ \mathrm{mg} \mathrm{N}$-glycanase for $3 \mathrm{~h}$ at $30^{\circ} \mathrm{C}$, and the digestions were terminated by the addition of trypsin $(40 \mu \mathrm{g} / \mathrm{mL}, 30 \mathrm{~min}$, $4^{\circ} \mathrm{C}$ ) and subsequent centrifugation of the intact spheroplasts through a $0.5 \mathrm{M}$ sucrose cushion $(5000 \mathrm{~g}, 10 \mathrm{~min})$ or precipitation of the solubilized spheroplasts and homogenate $(8 \%$ PEG $4000,30 \mathrm{~min}, 4^{\circ} \mathrm{C}$, followed by centrifugation $100000 \mathrm{~g}$, $15 \mathrm{~min}$ ), respectively, in the presence of a 4 -fold molar excess of bovine trypsin inhibitor and $100 \mu \mathrm{M}$ PMSF.

Nitrous Acid Deamination. A total of $150 \mu \mathrm{g}$ of photoaffinity-labeled plasma membrane vesicles (approximately $50000 \mathrm{cpm}$ ) was incubated at $25^{\circ} \mathrm{C}$ in $0.5 \mathrm{~mL}$ of $0.25 \mathrm{M}$ sodium acetate ( $\mathrm{pH} 3.5)$, in the presence of freshly dissolved
$0.2 \mathrm{M} \mathrm{NaNO}_{2}$. For subsequent TX-114 partitioning the reaction was terminated by precipitation with $10 \%$ TCA. Precipitates were washed successively with ice-cold 5\% TCA, acetone, and $70 \%$ ethanol, dried, dissolved in $75 \mu \mathrm{L}$ of $20 \mathrm{mM}$ Tris- $\mathrm{HCl}(\mathrm{pH}$ 7.2) $/ 0.5 \mathrm{mM}$ EDTA/5 mM DTT $/ 20 \%$ glycerol $/ 0.5 \%$ MEGA 10 , and analyzed by TX-114 partitioning. For subsequent analysis by centrifugation the membranes were spun through a cushion of $0.5 \mathrm{M}$ sucrose (in the same buffer as described above, omitting the detergent, $150000 \mathrm{~g}, 30 \mathrm{~min}$, $\left.4^{\circ} \mathrm{C}\right)$.

Photoaffinity Labeling. Labeling experiments were performed by incubating $400 \mu \mathrm{L}$ of plasma membranes or spheroplasts $(200 \mu \mathrm{g})$ in $0.25 \mathrm{M}$ sucrose (plasma membranes) or $1.25 \mathrm{M}$ sorbitol (spheroplasts) and $25 \mathrm{mM}$ MES (pH 6.2) $/ 50 \mathrm{mM} \mathrm{KCl} / 10 \mathrm{mM} \mathrm{MgCl} / 2 \mathrm{mM} \mathrm{MnCl} / 1 \mathrm{mM}$ IBMX $/ 0.5 \mathrm{mM} \beta$-mercaptoethanol $/ 0.5 \mathrm{mM}$ EDTA $/ 100 \mu \mathrm{M}$ $5^{\prime}$-AMP/protease inhibitors (see above) with $50 \mu \mathrm{Ci}$ of 8$\left.\mathrm{N}_{3}-{ }^{32} \mathrm{P}\right]$ cAMP in the wells of a ceramical serology plate at $4^{\circ} \mathrm{C}$ for $30 \mathrm{~min}$ in the presence or absence of $100 \mu \mathrm{M}$ nonradioactive cAMP. Samples were then irradiated at $254 \mathrm{~nm}$ with a UV hand lamp for $5 \mathrm{~min}$ at a distance of $2 \mathrm{~cm}$. The reaction was terminated by the addition of $100 \mu \mathrm{M}$ cAMP. Membranes or spheroplasts were spun through cushions of 0.5 M sucrose in the same buffer $(150000 \mathrm{~g}, 30 \mathrm{~min}$, or $5000 \mathrm{~g}, 10$ min, respectively). For subsequent fractionation, labeled spheroplasts were diluted with $50 \mathrm{mg}$ of unlabeled spheroplasts.

Enzyme assays were carried out according to published procedures in the presence of $0.25 \%$ octyl glucoside and 75 mM KCl: adenylate cyclase (Salomon et al., 1974), citrate synthase (Srere, 1965), NADH:cytochrome $c$ oxidoreductase (Dallner et al., 1966), succinate:cytochrome $c$ oxidoreductase (Lang et al., 1977), and hexokinase (Gruber et al., 1966).

Miscellaneous Procedures. The cAMP-binding assay (using $25 \mathrm{nCi}$ of $\left[{ }^{3} \mathrm{H}\right]$ cAMP per incubation and a filtration technique), photoaffinity labeling of mitochondria with $8-\mathrm{N}_{3}$ [32P]cAMP, hydrophilic/hydrophobic partitioning with TX114 , SDS-PAGE, fluorography, and protein determination were carried out as reported in previous papers (Müller \& Bandlow, 1989a-c). Alkaline extraction, using $250 \mu \mathrm{g}$ of photoaffinity-labeled plasma membranes in $500 \mu \mathrm{L}$ of $0.2 \mathrm{M}$ sodium carbonate $(\mathrm{pH} 11.5)$ was performed as described by Mostov et al. (1981).

\section{RESULTS}

Plasma Membranes Bind cAMP Specifically. Yeast plasma membranes bind a considerable fraction of the total cAMP that associates specifically with subcellular components. This is evident particularly when a fractionation scheme is applied (see Materials and Methods) that allows the recovery of more than $50 \%$ of the plasma membranes present in the cell homogenate (based on the yield of adenylate cyclase as a specific marker). In this procedure, designed to minimize losses during the preparation, a homogenate obtained from osmotically lysed spheroplasts was directly subjected to Percoll density gradient centrifugation. Plasma membranes, radiolabeled with concanavalin $\mathrm{A}$ as a specific marker and purified by two successive gradient centrifugations, were strongly enriched in adenylate cyclase activity and contained only minor contaminations from other cellular compartments (Figure 1). Similarly, the purity of the mitochondrial fraction was verified by the relative enrichments and recoveries of the specific markers, succinate: cytochrome $c$ oxidoreductase and citrate synthase, with the simultaneous deprivation of microsomal, cytosolic, and plasma membrane markers. Most of the cAMP-binding activity was recovered in the mitochondrial fraction (about 4-fold enrichment). But cAMP-binding to plasma membranes, which 


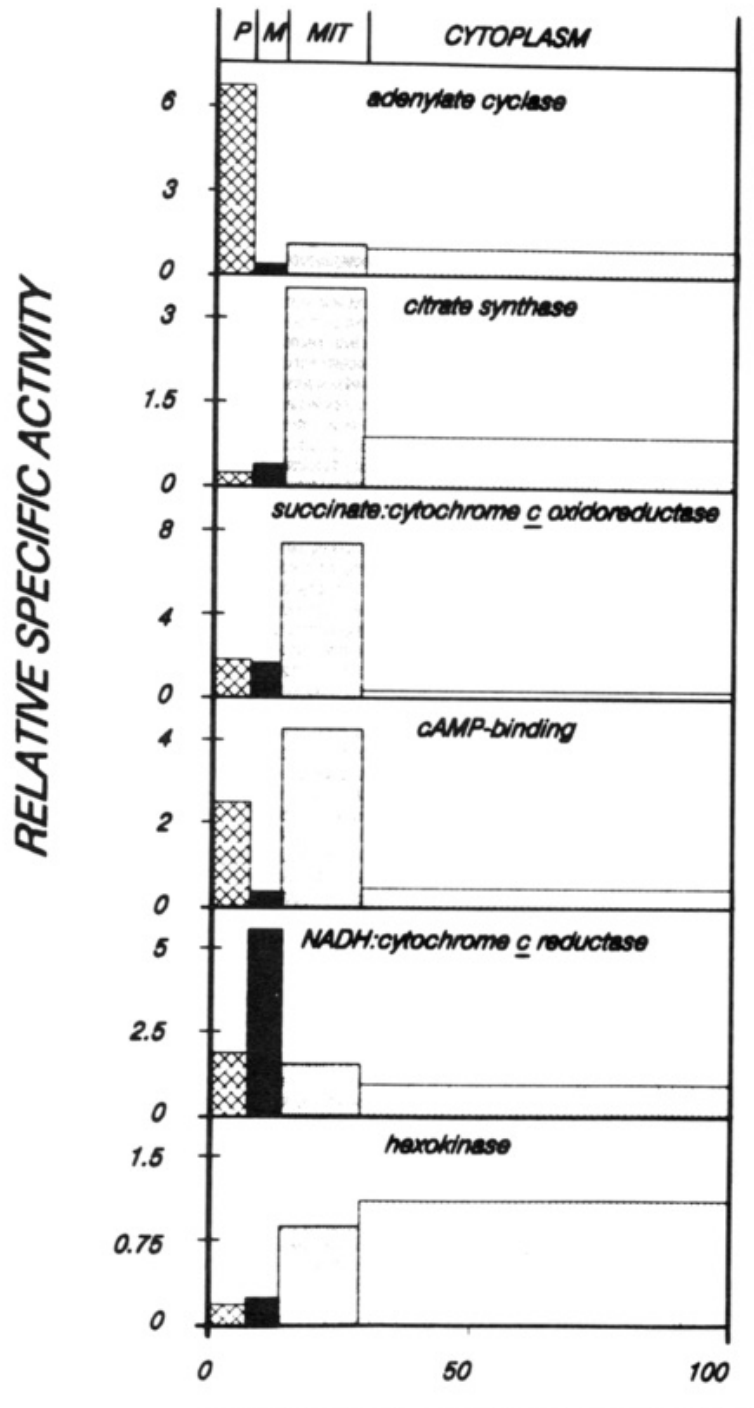

\% OF TOTAL CELLULAR PROTEIN

FIGURE 1: Subcellular distribution of cAMP-binding activity. Spheroplasts from exponentially grown yeast cells were fractionated into plasma membrane (P), mitochondria (MIT), microsomes (M), and cytoplasm. Each fraction was assayed for adenylate cyclase, citrate synthase, succinate:cytochrome $c$ oxidoreductase, NADH:cytochrome c oxidoreductase, hexokinase, and cAMP binding. The sum of protein recovered in all four compartments together was taken as $100 \%$. The relative specific activities measured in the homogenate were set at 1. The specific activities in the homogenate were as follows: adenylate cyclase, $41.4 \mathrm{pmol} \mathrm{mg}^{-1} \mathrm{~min}^{-1}$; citrate synthase, $16.5 \mathrm{nmol} \mathrm{mg}^{-1} \mathrm{~min}^{-1}$; succinate:cytochrome $c$ oxidoreductase, $34.1 \mathrm{nmol} \mathrm{mg^{-1 }} \mathrm{min}^{-1}$; NADH:cytochrome $c$ oxidoreductase, $2.4 \mathrm{nmol} \mathrm{mg}^{-1} \mathrm{~min}^{-1}$; hexokinase, $9.5 \mathrm{nmol} \mathrm{mg}^{-1} \mathrm{~min}^{-1}$; cAMP-binding, $1.4 \mathrm{pmol} \mathrm{mg}^{-1}$.

accounts for about $15 \%$ of the total cellular cAMP-binding capacity, was also significantly enriched (more than 2-fold) (Figure 1). The filter assay failed to demonstrate significant binding of cAMP to cytsolic proteins among which the R subunit of the soluble cAMP-dependent protein kinase A was to be expected. Similar observations have been ascribed earlier to the tight binding of the ligand and the low dissociation rate which makes this complex resistant to the removal of the ligand by extensive dialysis.

The binding of $\left[{ }^{3} \mathrm{H}\right] \mathrm{cAMP}$ to plasma membranes was completely competed for by excess unlabeled cAMP (Figure 2A) (but not by other adenosine 3'- and 5'-phosphate derivatives, data not shown). The Scatchard plot analysis [according to Fersht (1985)] of the cAMP binding to plasma membranes (Figure 2B) is in agreement with the existence of

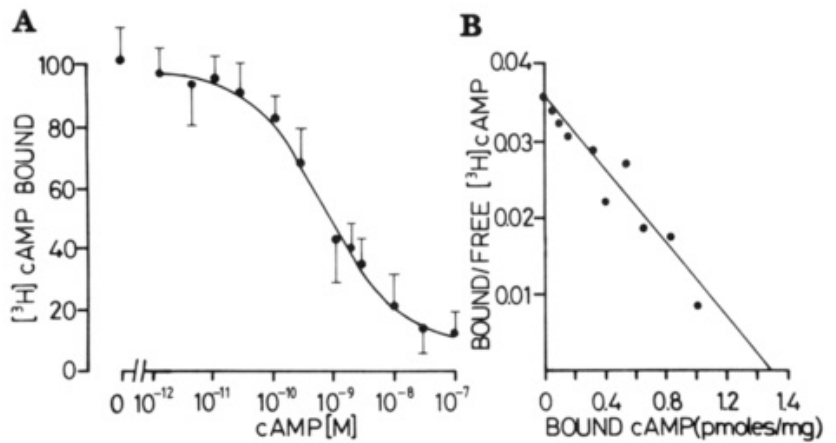

FIGURE 2: cAMP binding to plasma membranes. (A) Solubilized plasma membranes were incubated with $4 \mathrm{nM}\left[{ }^{3} \mathrm{H}\right] \mathrm{cAMP}$ in the presence of increasing concentrations of unlabeled cAMP and filtered (see Materials and Methods). Unspecific binding in the presence of $1 \mu \mathrm{M}$ unlabeled cAMP was subtracted from total binding. The results represent the means of four independent experiments (different membrane preparations, triplicate measurements each) with standard deviations shown by thin lines. (B) Scatchard plot derived from the binding data of the titration with unlabeled cAMP.

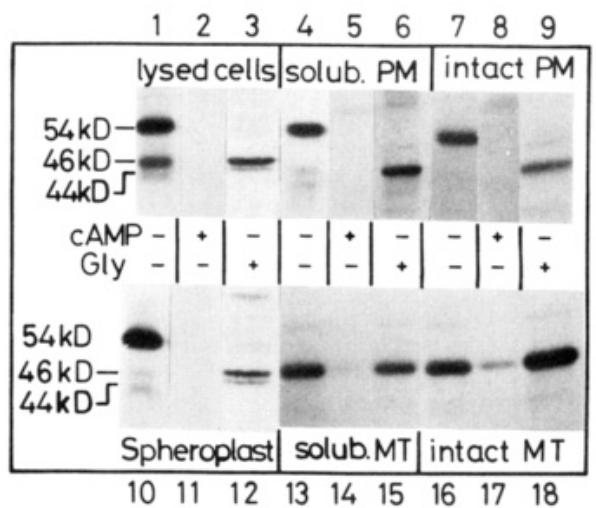

FIGURE 3: Photoaffinity labeling of cells and subcellular membranes with 8- $\mathrm{N}_{3}-\left[{ }^{32} \mathrm{P}\right] \mathrm{cAMP}$. Lysed (lanes $1-3$ ) and intact yeast spheroplasts (lanes 10-12), intact (lanes 7-9) and solubilized (lanes 4-6) plasma membrane vesicles, and intact (lanes 16-18) and solubilized (lanes 13-15) mitochondria were photoaffinity labeled with 8- $\mathrm{N}_{3}-\left[{ }^{32} \mathrm{P}\right] \mathrm{cAMP}$ in the presence or absence of a 100-fold molar excess of unlabeled cAMP. After solubilization and centrifugation, half of each supernatant was digested with $\mathrm{N}$-glycanase (Gly). TCA-precipitated and washed samples were analyzed by SDS-PAGE and autoradiography. Molecular masses, indicated at the left margin, were calculated from marker proteins run on the same gel.

a single type of high-affinity binding site for cAMP as the ligand. The dissociation constant, derived from the slope of the plot, $K_{\mathrm{d}}=5.9 \pm 0.7 \mathrm{nM}$, is about 1 order of magnitude higher than the one reported for the cytosolic R subunit from yeast (Hixson \& Krebs, 1980; Johnson et al., 1987). The concentration of binding sites calculated from the intercept of the abscissa is $1.34 \mathrm{pmol} / \mathrm{mg}$ of plasma membrane protein.

Plasma Membranes Contain a Distinct Glycosylated cAMP-Binding Protein. A single protein with an electrophoretic mobility corresponding to $54000 \mathrm{Da}$ was photoaffinity-labeled by $8-\mathrm{N}_{3}-\left[{ }^{32} \mathrm{P}\right]$ cAMP in intact and solubilized plasma membrane vesicles (Figure 3, lanes 4 and 7), spheroplasts (lane 10), and lysed cells (lane 1). In the presence of excess unlabeled cAMP no such band could be detected (lanes $3,5,8$, and 11 ), whereas $5^{\prime}$-AMP, which was routinely present in the labeling mixture, had no effect. This photoaffinitylabeled protein was clearly distinct from the mitochondrial cAMP receptor $\left(M_{\mathrm{r}}=46000\right.$; lanes 13-18). The simultaneous labeling of both cAMP-binding proteins was observed in osmotic lysates (lanes 1 and 3 ) whereas in intact spheroplasts (lane 10) only the protein from plasma membranes could be labeled. This argued that the plasma membrane provides an 


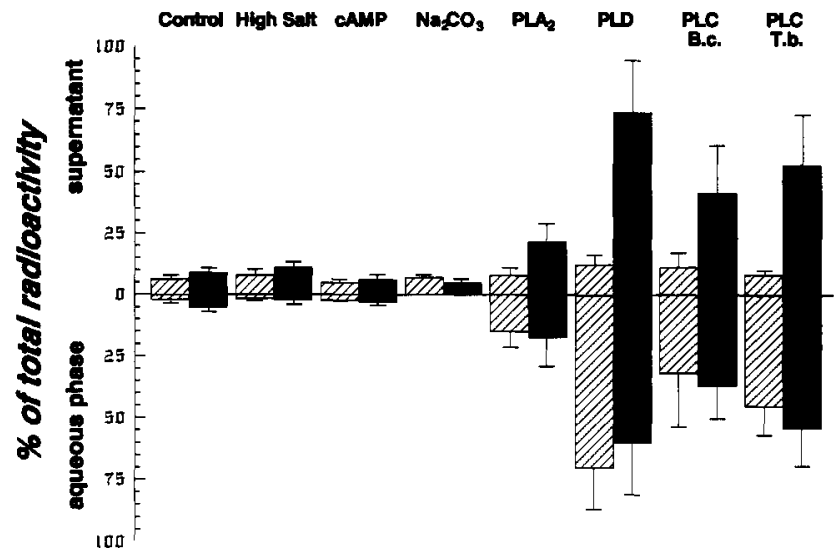

FIGURE 4: Membrane association of the plasma membrane cAMPbinding protein. $8-\mathrm{N}_{3} \cdot[32 \mathrm{P}] \mathrm{cAMP}$-labeled, photoaffinity-labeled plasma membranes were incubated in the presence (filled bars) or absence of $\mathrm{N}$-glycanase (open bars) in the absence of detergent as described under Materials and Methods. Aliquots were treated with $1 \mathrm{M} \mathrm{KCl}$ at $4^{\circ} \mathrm{C}$ (high salt) or $0.1 \mathrm{mM}$ cAMP at $30^{\circ} \mathrm{C}$ or $0.2 \mathrm{M}$ sodium carbonate $\left(\mathrm{Na}_{2} \mathrm{CO}_{3}\right)$ on ice or with PLA $2\left(\mathrm{PLA}_{2}\right)$ or $(\mathrm{G})$ PI-PLC from B. cereus (PLC, B.c.) or T. brucei (PLC, T.b.) or GPI-PLD from rabbit serum (PLD) or they were incubated without additions (control). Subsequently, half of each sample was subjected to TX-114 partitioning; the other half was centrifuged. The sum of the radioactivity in the aqueous and detergent phases, as well as in the supernatant and pellet fractions, respectively, was set at $100 \%$ in each experiment (pellet fractions and TX-114 phases are not shown) Results are the means of five independent experiments with standard deviations shown as thin bars.

effective accessibility barrier for cAMP to the inner compartments [see also Matsumoto et al. (1982b)] but not to the plasma membrane cAMP receptor and suggested that the cAMP-binding domain of the plasma membrane receptor is oriented toward the extracellular space.

It is noteworthy that treatment of solubilized spheroplasts or plasma membranes with $\mathrm{N}$-glycanase reduced the molecular weight of the photoaffinity-labeled plasma membrane cAMP-binding protein to approximately $44000-46000$ (lanes $3,6,9$, and 12 ), providing evidence for its glycoprotein nature. The deglycosylated product (corresponding to the faster moving of the two bands) nearly comigrated with its mitochondrial counterpart in SDS-PAGE (lanes 3 and 12), which latter remained unaffected by this treatment (lanes 15 and 18).

The CAMP Receptor Is Anchored to the Plasma Membrane by Lipid and Carbohydrate. In mitochondria a cAMP-binding protein has been found recently to be anchored in the inner membrane through a lipid structure containing phosphatidylinositol (Müller \& Bandlow, 1989a). Lipid-modified proteins have also been described in the plasma membrane from yeast (Conzelmann et al., 1988, 1990; Vai et al., 1990). To test the possibility that the cAMP receptor is anchored to the plasma membrane via such a phosphatidylinositol moiety we examined the sensitivity of membrane association to (G)PI-PL's. Release from the membrane and conversion of the amphiphilic to a hydrophilic soluble form were monitored by examining both its release into the soluble supernatant [Figure 4, upper panel; pellet (not shown) and supernatant together represent $100 \%$ ] and its recovery from the aqueous phase in TX-114 partitioning [Figure 4, lower panel; aqueous and TX-114 (not shown) phases together are set as $100 \%$ ]. The figure shows that the uncleaved, membrane-anchored version of the cAMP-binding protein (control) could be recovered almost quantitatively from the membranous pellet in the one and from the hydrophobic detergent phase in the other experiment. High salt was completely ineffective in extracting the protein into the soluble supernatant or the aqueous phase in partitioning, as were also extractions with alkaline sodium carbonate and CAMP, indicating a tight anchorage in the membrane. This behavior was independent of whether the protein had been deglycosylated (filled bars) or not (hatched bars). When, on the other hand, plasma membranes were treated with GPI-specific phospholipases, a significant portion of the cAMP receptor could be released into the soluble fraction, provided the membranes had been pretreated with $\mathrm{N}$-glycanase (upper panel). Likewise, comparable amounts of hydrophilic cAMP receptor were recovered from the aqueous phase when a membrane digest by PLD was partitioned (independent of the presence or absence of carbohydrate side chains in this case; lower panel). Thus, membrane release of the cAMP receptor requires the cleavage both of the covalently attached lipid (rendering the protein hydrophilic) and of carbohydrate moieties (eliminating polar interactions between the protein and membrane components). Interestingly, membrane release by exogenous phospholipases depended on the type and source of the enzyme. PLA $A_{2}$ released from the membrane (after deglycosylation) and converted into the hydrophilic form only a small portion of the affinity-labeled receptor. More effective were (G)PI-PLC's from B. cereus (Stieger et al., 1986) (up to 50\% cleavage) and T. brucei (Bülow \& Overath, 1986) (up to 75\% cleavage). In contrast, "classical" GPI anchors are cleaved by these enzymes nearly quantitatively [for a review see Low (1989)]. However, some GPI-anchored proteins exhibit restricted susceptibility to (G)PI-PL's [for a review see Ferguson and Williams (1988); Low, 1989]. They were shown to carry substitutions at the inositol ring. The anchor of the cAMP receptor protein from yeast plasma membranes may be modified in a way that also impedes access of PLA 2 and (G)PI-PLC to their substrate sites. On the other hand, treatment with exogenous GPI-PLD from rabbit serum (Davitz et al., 1987, 1989) released the cAMP-binding protein from the membrane very efficiently.

The gel electrophoretic patterns of photoaffinity-labeled cAMP-binding protein from plasma membranes with and without treatment by GPI-PLD are displayed in Figure 5 . This figure exemplifies the results compiled in Figure 4 and documents that treatment with GPI-PLD did not visibly change the electrophoretic mobility of the cAMP receptor protein but completely abolished its amphiphilic character. This was demonstrated by segregation of the CAMP receptor into the aqueous phase in TX-114 partitioning (Figure 5, compare lanes 3 and 4 in panel a with the respective lanes in panel d). Cleavage by phospholipases, preferentially by GPI-PLD, confirms that the membrane anchorage of the cAMP-binding protein from the plasma membrane is effected through a covalently linked lipid-containing structure. The anchor is under present investigation, and the detailed analysis of the structure, which has the characteristics of a glycolipid, will be published elsewhere. Interestingly, removal of the phosphatidylinositol moiety was prerequisite but not sufficient for membrane release. Liberation from the membrane into the supernatant fraction was significantly enhanced by high salt and $\alpha$-MMP (compare lanes 1 and 2 in panel $d$ with lanes 5 and 6 in panel e or lanes 9 and 10 in panel f). Both agents were inefficient in the absence of lipase (panels $b$ and $c$, lanes $5-12$ ). These data strengthen the view that the protein is not kept in the membrane exclusively by the covalently attached glycolipid anchor but, in addition, by accessory interactions of the carbohydrate side chains with so far unidentified membrane structures (receptor complex).

Figure 5 provided also further evidence for the extracellular location of the cAMP-binding protein. In intact spheroplasts 


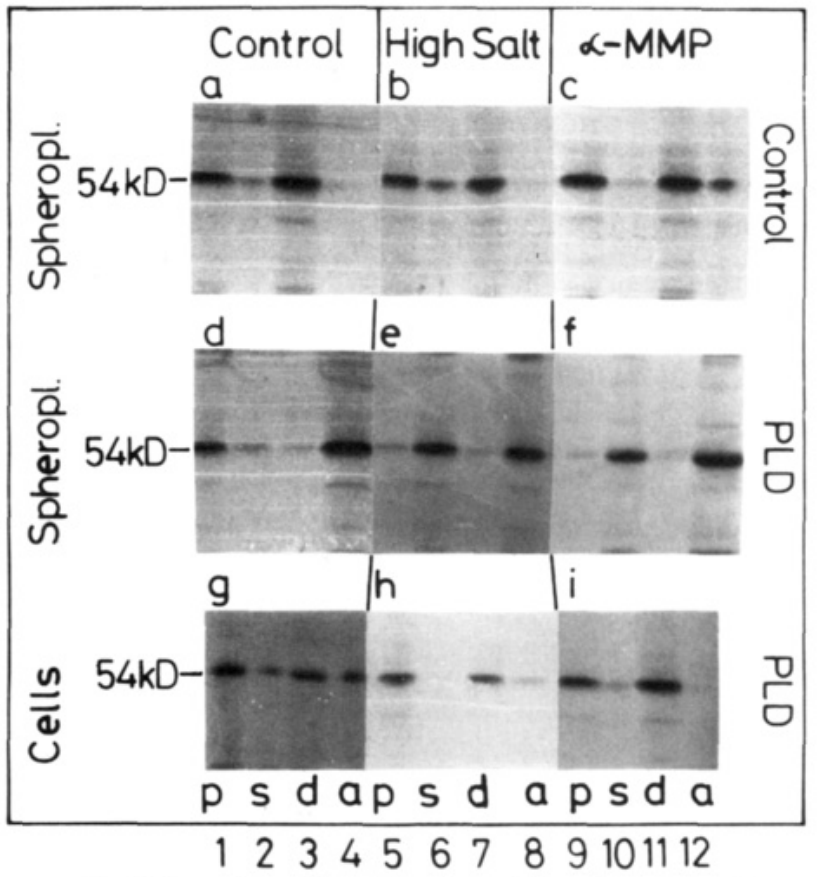

FIGURE 5: Release from the cell surface of the plasma membrane cAMP receptor. A total of $125 \mu \mathrm{g}$ of spheroplasts (spheropl.) or cells was photoaffinity labeled and incubated in the presence or absence (control) of GPI-PLD from rabbit serum (PLD) and then adjusted to $1 \mathrm{M} \mathrm{KCl}$ (high salt) or $10 \mathrm{mM} \alpha$-MMP, whereas the control received buffer only. After $30 \mathrm{~min}$, half of each sample was subjected to TX-114 partitioning, the other half was centrifuged. The TCAprecipitated and acetone/ethanol-washed detergent (d) and aqueous phases (a) from partitioning and pellet (p) and supernatant (s) fractions from the centrifugation, respectively, were analyzed by SDS-PAGE and autoradiography.

(panels d, e, and f; lanes 4, 8, and 12), but not in whole cells (panels g, h, and i; lanes 4, 8, and 12), not even in the presence of high salt and $\alpha$-MMP (panels $\mathrm{h}$ and i; lanes 6 and 10), GPI-PLD had access to the lipidic anchor structure from the outside. Thus, the cAMP-binding protein is presumably located at the periplasmic side of the plasma membrane.

Topological Studies on the CAMP-Binding Protein from Plasma Membranes. GPI-anchored plasma membrane proteins characterized from higher eukaryotic cells so far have been found to be located exclusively at the extracellular face of the plasma membrane [for a review see Low (1987); Cross, 1990]. In order to extend these studies to yeast we undertook a detailed study on the topology of the cAMP receptor from yeast plasma membranes. For this purpose we prepared plasma membrane vesicles in both membrane orientations. The efficiency of the separation of inside out and outside out vesicles by concanavalin A affinity chromatography (see Materials and Methods) was controlled by testing the accessibility to proteolytic digestion of proteins with known membrane topology, e.g., adenylate cyclase, which is associated with the inner face of plasma membranes (Mitts et al., 1990). In the experiment shown in Figure 6A the two vesicle populations were digested separately with increasing concentrations of trypsin and, after termination of the incubation, assayed for adenylate cyclase activity. Figure $6 \mathrm{~A}$ shows that trypsin inactivated adenylate cyclase from detergent-solubilized vesicles $(X)$ and from vesicles sonicated in the presence of trypsin (•) with similar kinetics, showing that adenylate cyclase has comparable intrinsic protease sensitivities in both types of vesicles. By contrast, without further treatment $(0)$, adenylate cyclase from outside out vesicles was about 6 times more resistant to the protease than that from the inverted ones. This inactivation behavior agrees well with the predicted sidedness of the plasma membrane vesicles after separation by concanavalin A-Sepharose affinity chromatography.

For determining the topological orientation of the cAMP receptor protein, similarly prepared inside out and outside out vesicles, photoaffinity labeled during sonication, were incubated with either serum GPI-PLD or nitrous acid [which is known to cleave GPI anchors at the characteristic non-acetylated glucosamine residue; see Ferguson and Cross (1984); Ferguson et al., 1985]. The distribution of the labeled cAMP-binding protein between a supernatant and a pellet fraction obtained after centrifugation and between a detergent and an aqueous phase after TX-114 partitioning was analyzed by SDS-PAGE and autoradiography. As shown in Figure 6B, GPI-PLD converted the cAMP-binding protein from outside out vesicles from the membrane-bound amphiphilic form (Figure 6B, lanes 1 and 2) to a soluble hydrophilic form (lanes 3 and 4). By contrast, treatment of inside out vesicles with GPI-PLD (Figure 6C) had no effect on the location and amphiphilicity of the protein (Figure 6C, lanes 3 and 4). Also, nitrous acid significantly increased the portion of both the soluble and the hydrophilic form in outside out vesicles in a concentrationdependent manner (Figure 6B, lanes 5 and 7, and 6 and 8, respectively). After treatment of inside out vesicles with nitrous acid, the major fraction of the receptor protein remained associated with the inverted vesicle fraction (lanes 5 and 7). However, in this case the protein was recovered from the aqueous phase after hydrophobic/hydrophilic partitioning (Figure 6C, lanes 6 and 8). Since nitrous acid is membrane permeable, it cleaves the glycolipid anchor in either orientation, leaving the cAMP receptor trapped in the lumen only of inside out vesicles. This experiment presents strong evidence that the head group of the anchor's lipid structure is inserted into the outer leaflet of the lipid bilayer of the plasma membrane, the core protein facing the extracellular space.

The identical conclusion can be drawn from experiments, where the accessibility to $\mathrm{N}$-glycanase was assayed. The above-found orientation of the cAMP receptor protein implies that the carbohydrate moiety(ies) of its $\mathrm{N}$-glycosidic side chain(s) protrude into the extracellular space. This prediction was tested. Photoaffinity-labeled cAMP-binding protein in spheroplasts and inside out or outside out plasma membrane vesicles and solubilized plasma membranes was digested with $\mathrm{N}$-glycanase, and the accessibility of the carbohydrate side chains was analyzed by SDS-PAGE and autoradiography. $\mathrm{N}$-Glycanase treatment of outside out vesicles, solubilized membranes, and spheroplasts decreased the electrophoretic mobility of the photolabeled product from a position corresponding to $54 \mathrm{kDa}$ to two species of 47 and $44 \mathrm{kDa}$ (Figure $6 \mathrm{D}$, lanes 4,6 and 8 ; the reason for the heterogeneity is not known, but it may be related to incomplete digestion). The molecular integrity of the receptors was preserved in inside out vesicles (lane 2). By contrast, in the control where inside out vesicles had been sonicated together with $\mathrm{N}$-glycanase and then incubated, the same reduction in apparent molecular weight was observed as in spheroplasts and outside out vesicles (not shown). Thus, the N-glycosidic carbohydrate chain(s) of the plasma membrane cAMP receptor can be removed only when the enzyme has access to the extracellular face of the membrane.

Genetic Relationship of the Plasma Membrane cAMP Receptor to the R Subunit of Cytoplasmic Protein Kinase A. The R subunit of PKA has been reported to occur associated with various membranes including plasma membranes in yeast (Behrens \& Mazon, 1988). In each case where topological studies had been performed it was found that it was bound 
B

A

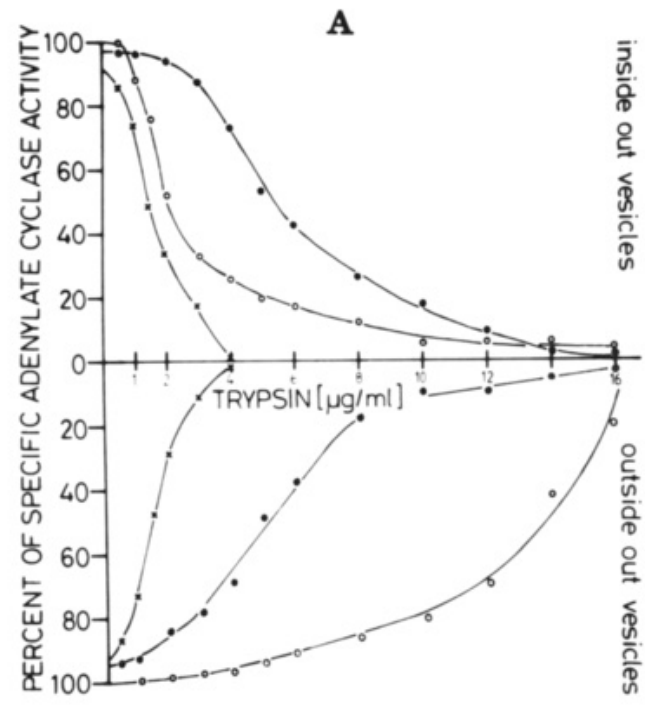

OUTSIDE OUT VESICLES

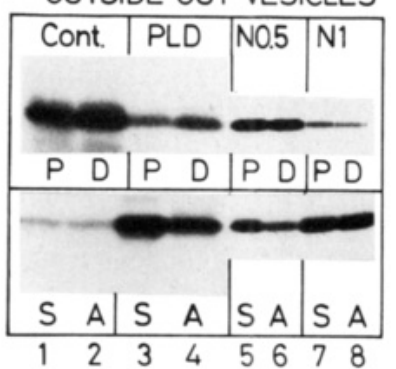

INSIDE OUT VESICLES

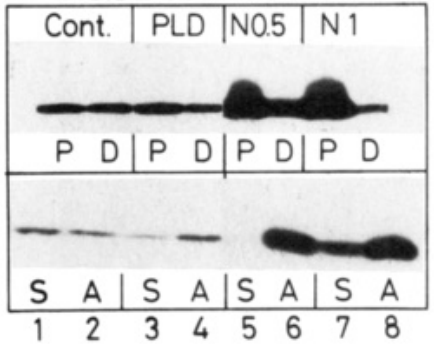

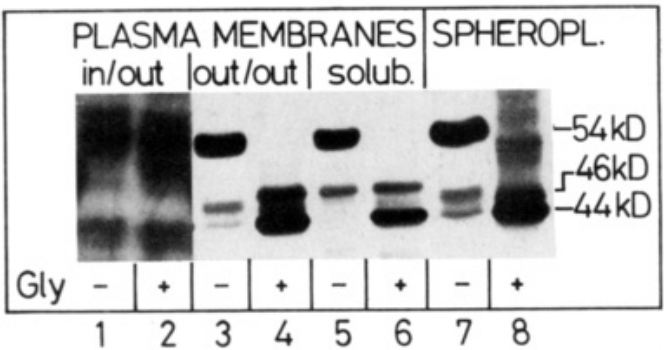

FIGURE 6: (Panel A) Sidedness of plasma membrane vesicles. Plasma membrane vesicles (inside out and outside out) were incubated with various concentrations of trypsin (pretreated with TLCK) in the presence $(X)$ or absence $(0)$ of $1 \%$ TX-100 or during mild ultrasonic treatment (•). After the addition of a stop solution containing a 4-fold molar excess of soy bean trypsin inhibitor, $200 \mu \mathrm{M}$ PMSF, and $1 \%$ BSA, the vesicles were centrifuged through a $1-\mathrm{mL}$ cushion of $0.5 \mathrm{M}$ sucrose. The vesicle pellet was washed, dissolved with $1 \% \mathrm{TX}-100$, and centrifuged. The supernatant was assayed for adenylate cyclase activity $(n=4)$. The specific activity, measured in control incubations of the two vesicle populations (absence of trypsin) was taken as $100 \%$. Only minor differences were found when this control incubation was carried out in the absence or presence of detergent or sonication. (Panels B and C) Topological orientation of the membrane anchor. Plasma membrane vesicles were photoaffinity labeled with 8- $\mathrm{N}_{3}-\left[{ }^{32} \mathrm{P}\right] \mathrm{cAMP}$ during ultrasonic oscillation (see Materials and Methods). Reisolated vesicles were separated into outside out (B) and inside out vesicles (C) and subsequently subjected to GPI-PLD treatment (PLD) or nitrous acid deamination for 0.5 $\mathrm{h}(\mathrm{N} 0.5)$ or $1 \mathrm{~h}(\mathrm{~N} \mathrm{1})$, or a control incubation (cont.) was carried out $\left(60 \mathrm{~min}, 37^{\circ} \mathrm{C}\right)$. Half of each sample was centrifuged through a 0.5 -mL cushion of $0.5 \mathrm{M}$ sucrose. The pellet (P) was dissolved in sample buffer. The supernatant fraction (S), withdrawn from the top of the sucrose layer, was precipitated with 5\% TCA and dissolved in sample buffer. The other half of the samples was subjected to TX-114 partitioning. Both, the detergent (D) and aqueous (A) phases, were precipitated with TCA and dissolved in sample buffer. All samples were analyzed by SDS-PAGE and autoradiography. (Panel D) Topological orientation of the carbohydrate moiety. Yeast spheroplasts were photoaffinity labeled with 8- $\left.\mathrm{N}_{3}-{ }^{32} \mathrm{P}\right]$ cAMP. From one aliquot, plasma membranes were prepared and separated into inside out (in/out) and outside out (out/out) vesicles or solubilized with detergent (solub.); the other aliquot was left. Plasma membrane preparations and spheroplasts (spheropl.) were incubated in the presence or absence of N-glycanase (Gly). TCA-precipitated pellets were solubilized with sample buffer and analyzed by SDS-PAGE and autoradiography. Molecular masses shown on the right margin were derived from metabolically labeled (described elsewhere) and affinity-purified mitochondrial (46 kDa), plasma membrane (54 kDa), and deglycosylated plasma membrane (44 kDa) cAMP-binding proteins, run in parallel on the same gel.

to the cytoplasmic face of the respective membrane. In all these locations the complex was released from the membrane and the active kinase was dissociated from the inactive complex by the presence of cAMP (Nairn et al., 1985). The association with the membrane of the complex was suggested to be due to protein-protein interactions (Bregman et al., 1989). Although the anchorage by a lipid structure and the location at the periplasmic face of the plasma membrane argue that the cAMP receptor of the plasma membrane constitutes a novel type of cAMP-binding protein and is independent of the cytoplasmic $\mathrm{R}$ subunit, the most compelling evidence for the nonidentity of the two proteins comes from genetic experiments. Mutant strain EG273-5A, deleted for BCY1, the locus encoding the R subunit of the cytoplasmic protein kinase A (Cannon \& Tatchell, 1987; Toda et al., 1987), was analyzed for the presence of a cAMP receptor protein in plasma membranes. As expected, a signal was absent from the cytoplasmic fractions from the $b c y l$, mutant strain, irrespective of whether the labeling was carried out with intact spheroplasts or with the isolated cytoplasmic fraction (Figure 7, lanes 1 and 5, respectively). Lane 4 shows the authentic affinity-labeled product from wild-type plasma membranes for comparison (ma). A similar signal (although at a position indicating a slightly lower electrophoretic mobility) was observed in plasma membranes from bcyl mutant cells. It could be detected in

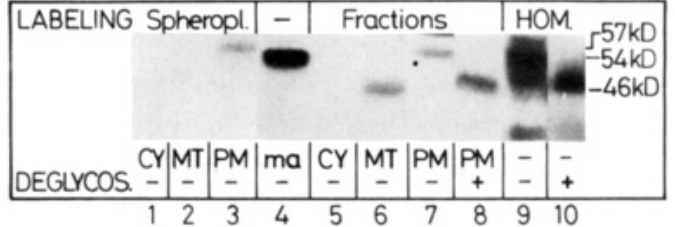

FIGURE 7: Photoaffinity labeling of a bcyl disruption mutant lacking the R subunit of PKA. Subcellular fractions (labeling fractions), total homogenate (labeling hom.), and spheroplasts (labeling spheropl.) were photoaffinity labeled with $8-\mathrm{N}_{3}-\left[{ }^{32} \mathrm{P}\right] \mathrm{cAMP}$. Spheroplasts were subsequently fractionated into cytoplasm (CY), mitochondria (MT), and plasma membranes (PM). Half of the plasma membrane fraction and half of the homogenate were deglycosylated with $\mathrm{N}$-glycanase (deglycos.), whereas the other fractions remained untreated. All samples were separated by SDS-PAGE and autoradiographed. Photoaffinity-labeled plasma membranes of the wild-type yeast strain were run in a parallel lane for comparison (ma). Molecular masses shown on the right margin were derived from marker proteins run on the same gel.

8- $\mathrm{N}_{3}-\left[{ }^{32} \mathrm{P}\right] \mathrm{cAMP}-\mathrm{labeled}$, isolated plasma membranes, and homogenate (lanes 3, 7, and 9). The portion of photoaffinity-labeled cAMP receptor associated with plasma membranes was significantly lower (lanes 3 and 7) than the total amount recovered in the homogenate (lane 9), suggesting that in the mutant the receptor (or a precursor) is retained in some intracellular compartment, presumably the ER or Golgi. The 
higher apparent molecular mass of the cAMP-binding protein attributed to this signal ( $57 \mathrm{kDa}$ compared to $54 \mathrm{kDa}$ of the plasma membrane wild-type cAMP receptor) may be due to strain-specific differences or an altered or lacking (presumably C-terminal) proteolytic processing in the mutant strain. The apparent molecular mass could, however, be reduced to $46 \mathrm{kDa}$ by treatment with $\mathrm{N}$-glycanase (lanes 8 and 10 ), arguing that $\mathrm{N}$-glycosylation occurs in a similar fashion to that in the wild type. In addition, a signal corresponding to a $M_{\mathrm{r}}$ of 46000 was found in the mitochondrial fraction and in the homogenate of the mutant strain disrupted for $B C Y 1$, proving the presence of the mitochondrial isoprotein (lanes 6 and 9). This protein was unchanged in comparison with the wild-type situation (compare with Figure 3 ). It nearly comigrated with the deglycosylated plasma membrane cAMP receptor in the photoaffinity-labeled homogenate (lane 10). The data prove that the CAMP-binding proteins from plasma membranes and mitochondria are genetically unrelated to the cytoplasmic $\mathrm{R}$ subunit encoded by the $B C Y I$ gene.

\section{Discussion}

Like all eukaryotes, the yeast $S$. cerevisiae contains a cAMP-dependent protein kinase in the cytoplasm. A single gene [called $S R A I$ by Cannon and Tatchell (1987) or REGl by Kunisawa et al. (1987) or $B C Y 1$ by Toda et al. (1987)] encodes its $R$ subunit. Recently, an additional cAMP-binding $R$ subunit of a cAMP-dependent protein kinase has been discovered in yeast mitochondria (Rödel et al., 1985; Müller \& Bandlow, 1987). It is bound to the outer surface of the inner membrane by an anchor containing phosphatidylinositol (Müller \& Bandlow, 1989a-c), a covalent modification typical for certain plasma membrane (glyco)proteins in higher and lower eukaryotes. GPI-anchored proteins have, indeed, been detected in yeast plasma membranes (Conzelmann et al., 1988, 1990; Vai et al., 1990). In the course of the analysis of cAMP-dependent effects not mediated by the cytoplasmic PKA and recalling an earlier report on the presence of a cAMP-binding protein(s) in yeast plasma membranes (Jaynes et al., 1980), we examined cAMP binding to plasma membranes and describe here the identification of a phosphatidylinositol-modified cAMP-binding protein.

Genetic evidence excludes that the plasma membrane cAMP receptor is derived from the same gene $(B C Y l)$ as the $\mathrm{R}$ subunit of yeast cytoplasmic PKA. In addition, several lines of evidence strongly suggest that this protein also physically differs from the mitochondrial species. First, extensive cross-contamination of our plasma membrane preparations by mitochondria can be excluded. Our plasmalemma preparation is significantly deprived of both soluble and membrane-bound mitochondrial marker enzymes and concomitantly enriched in adenylate cyclase activity. Second, the size of the two membrane-associated cAMP-binding proteins differs markedly [plasma membrane $54 \mathrm{kDa}$, mitochondria $46 \mathrm{kDa}$; the soluble cytosolic cAMP-binding $\mathrm{R}$ subunit of yeast protein kinase $\mathrm{A}$ has a molecular mass of $51 \mathrm{kDa}$ for comparison (Hixson \& Krebs, 1980; Wingender-Drissen, 1983)]. Third, only the plasma membrane cAMP receptor is extensively $\mathrm{N}$ glycosylated, which is consistent with its periplasmic orientation, whereas mitochondria lack a glycosyltransferase system. Fourth, although both proteins are anchored in the membrane by a covalently attached lipid structure containing glycerylphosphoinositol, only the anchor of the plasma membrane protein contains non-acetylated glucosamine (evident from the destruction by nitrous acid and from metabolic labeling studies that will be published elsewhere). The detailed analysis of the two anchors and the study of the relationship of their core proteins will be subjects of future efforts.

The lipid-modified plasma membrane cAMP reeptor is released from spheroplasts by exogenous GPI-PLD or by nitrous acid deamination in the presence of high salt without a noticeable shift in electrophoretic mobility in SDS-PAGE. On the other hand, it resists treatment of plasma membranes with high salt or alkaline sodium carbonate. Thus, membrane association of this protein is accomplished by its glycolipidic anchor and not by a proteinaceous transmembrane domain or by protein-protein interactions. The carbohydrate side chain appears to be involved in an additional salt-dissociable interaction with the membrane. After lipolytic cleavage of the membrane anchor, $\alpha$-MMP (or high salt) facilitates, in a competitive fashion, the dissociation from the membrane. Removal of the side chain by N-glycanase exerts a similar effect. It may be speculated that these polar interactions between the carbohydrate side chain(s) of the cAMP receptor and the membrane keep the protein in contact either with a hypothetical anchor-degrading enzyme (phospholipase) or with a possible target. The prevention from dissociation from the cell surface is reminiscent of the situation with heparan sulfate proteoglycan in rat hepatocytes. This glycoprotein is bound to the plasma membrane through a phosphatidylinositol moiety. After cleavage of the membrane anchor by an intrinsic phospholipase $\mathrm{C}$, the proteoglycan, with myo-inositol phosphate still attached to the core protein, remains membrane-associated via a cell surface receptor that recognizes the myo-inositol phosphate moiety and is subsequently internalized. Exogenous myo-inositol phosphate derivatives cause competitive displacement of the proteoglycan and exclusion from the cell matrix (Ishihara et al., 1987).

It has been postulated that the binding of PKA to various intracellular membranes is mediated by bipolar interactions of the R subunit with integral membrane proteins (Sakar et al., 1984; Bregman et al., 1989; see Introduction). N-Terminal myristylation, demonstrated for the $\mathrm{C}$ subunit of PKA, may assist membrane attachment of the inactive complex (Carr et al., 1982; Kamps et al., 1985; Clegg et al., 1989). We have shown here that covalent modification by complete phospholipid structures provides an additional mode of membrane association of CAMP-binding proteins. cAMP has been observed to cause the release of an active $C$ subunit from membrane-associated PKA's (Nairn et al., 1985), whereas the second messenger has no effect on the protein described here.

We present strong evidence that the cAMP-binding protein from yeast plasma membranes is oriented toward the extracellular space. First, right side out plasma membrane vesicles, characterized by their binding to concanavalin A-Sepharose via their externally exposed mannoproteins, lose the cAMP. binding protein upon treatment with GPI-PLD or upon nitrous acid deamination by contrast to inverted vesicles. Second, GPI-PLD liberates the cAMP-binding protein from sealed spheroplasts. Third, N-glycanase has access to the $\mathrm{N}$ glycosidic side chain(s) of the receptor in spheroplasts and outside out plasma membrane vesicles but not in inside out vesicles. Fourth, the membrane-impermeable $8-\mathrm{N}_{3}$-cAMP labels the plasma membrane cAMP receptor in intact spheroplasts. This deduced topology is in agreement with the current view of the biogenesis of both carbohydrate- and GPI-modified membrane proteins. Both N-glycosylation and replacement of a transient proteinaceous transmembrane domain by a glycolipid in a pseudotranspeptidation reaction are thought to occur in the endoplasmic reticulum (Takami et al., 1988; Caras et al., 1989; Caras \& Weddell, 1989; Doering et al., 1990). After their passage through the secretory pathway 
these proteins have an outward orientation.

It is interesting to note in this context that recently evidence for the extracellular occurrence of a cAMP-dependent protein kinase was found in HeLa, chinese hamster ovary, and mouse lymphoma $S 49$ cells (Kübler et al., 1989). As in the case of the yeast plasma membrane cAMP receptor, the constituent cAMP-binding protein of this kinase was not released by cAMP alone. Surprisingly, it was also observed that thrombin-stimulated rabbit platelets release a protein kinase that specifically phosphorylates a plasma protein in a cAMP-dependent manner (Korc-Grodzicki et al., 1988). Unfortunately, the mode of membrane anchorage has not been determined in these cases.

The extracellular location of the cAMP-binding protein facing the periplasmic space raises the question of the availability of CAMP at the cell surface. Extracellular cAMP most likely originates from the secretion of cytoplasmic cAMP into the cell exterior rather than from the conversion of extracellular ATP involving enzymes at the cell surface (Trams, 1974; Wen et al., 1985). Recently, extrusion of cAMP from intact mammalian cells with the characteristics of an active transport was reported (Brunton \& Heasley, 1988). In addition, Smith et al. (1990) demonstrated the extrusion of cAMP from yeast cells into the medium, the extracellular levels being 10-100 times higher than the intracellular pool. Interestingly, the extracellular level of cAMP does not fluctuate during the cell cycle, making a role of the lipid-modified cAMP-binding protein of the plasma membrane in the regulation of the cell cycle unlikely.

With the exception of the extracellular cAMP receptor from Dictyostelium discoideum all cAMP-binding proteins in eukaryotic cells are assumed to function as regulatory subunits of cAMP-dependent protein kinases [for a review see Lohmann and Walter (1984)]. cAMP-dependent protein phosphorylation was believed to be mediated exclusively through the cytoplasmic PKA and its isoforms (Corbin et al., 1977; Flockart \& Corbin, 1982; Lohmann et al., 1984; DeCamilli et al., 1986). Although the $\mathrm{C}$ subunit of the cAMP-dependent protein kinase in mitochondria, which phosphorylates a $40-\mathrm{kDa}$ inner membrane protein in a cAMP-dependent manner, has not yet been physically identified, the corresponding cAMP-binding protein represents the first example of a phosphatidylinositol-anchored $\mathrm{R}$ subunit of a $\mathrm{cAMP}$-dependent protein kinase (Müller \& Bandlow, 1987). But protein phosphorylation occurs only after the lipolytic release of the RC complex from the membrane (Müller \& Bandlow, 1989c). Thus, lipid modification seems to provide a novel mode for membrane association and regulation of CAMP-dependent protein kinases, epistatic over the modulation by cAMP. The extracellular orientation of the cAMP receptor, in addition, implies the reconsideration of the exclusive role of cAMP as an intracellular second messenger in yeast (and perhaps in other cells). It remains to be established whether the GPI-anchored cAMP-binding ectoprotein of the plasma membrane belongs to the same type of protein kinase as the mitochondrial isoprotein.

\section{ACKNOWLEDGMENTS}

We thank K. Tatchell, North Carolina State University at Raleigh, for providing us with $b c y l$-defective strains and a bcy $1:: U R A 3$ disruption construct. We are also indebted to $\mathrm{G}$. A. M. Cross for sending us his manuscript (Cross, 1990) prior to publication. GPI-PLC from $T$. brucei was the gracious donation of P. Overath, Max-Planck-Institut für Biophysik, Tübingen, and GPI-PLD from rabbit serum was the kind gift of W. Gutensohn, Institut für Anthropologie and Humangenetik, Universität München. We are grateful to G. Strobel for her help with the maintenance of strains and for the construction of the heterozygous bcyl disruption strain.

Registry No. cAMP, 60-92-4.

\section{REFERENCES}

Achstetter, T., Emter, O., Ehmann, C., \& Wolf., D. H. (1984) J. Biol. Chem. 259, 13334-13341.

Baroni, M. D., Martegani, E., Monti, P., \& Alberghina, L. (1989) Mol. Cell. Biol. 9, 2715-2723.

Beebe, S. J., \& Corbin, J. D. (1986) in The Enzymes (Boyer, P. D., Ed.) Vol. 17, pp 41-111, Academic Press, Orlando, FL.

Behrens, M. M., \& Mazon, M. J. (1988) Biochem. Biophys. Res. Commun. 151, 561-567.

Bregman, D. B., Rhattacharyya, N., \& Rubin, C. S. (1989) J. Biol. Chem. 264, 4648-4656.

Brunton, L. L., \& Heasley, L. E. (1985) Methods Enzymol. 159, 83-93.

Bülow, R., \& Overath, P. (1986) J. Biol. Chem. 261, 11918-18775.

Cannon, J. F., \& Tatchell, K. (1987) Mol. Cell. Biol. 7, 2653-2663.

Caras, I. W., \& Weddell, G. N. (1989) Science 243, 1196-1198.

Caras, I. W., Weddell, G. N., \& Williams, S. R. (1989) J. Cell Biol. 108, 1387-1396.

Carr, S. A., Biemann, K., Shoji, S., Parmele, D. C., \& Titani, K. (1982) Proc. Natl. Acad. Sci. U.S.A. 79, 6128-6131.

Clegg, C. H., Ran, W., Uhler, M. D., \& McKnight, G. S. (1989) J. Biol. Chem. 264, 20140-20146.

Conzelmann, A., Riezman, H., Desponds, C., \& Bron, C. (1988) EMBO J. 7, 2233-2240.

Conzelmann, A., Fankhauser, C., \& Desponds, C. (1990) EMBO J. 9, 653-661.

Corbin, J. D., Sugden, P. H., Lincoln, T. M., \& Keeley, S. L. (1977) J. Biol. Chem. 252, 3854-3861.

Cross, G. A. M. (1990) Annu. Rev. Cell Biol. 6, 1-39.

Dallner, G., Siekevitz, P., \& Palade, G. E. (1966) J. Cell Biol. $30,97-117$.

Davitz, M. A., Hereld, D., Shak, S., Krakow, J., Englund, P. T., \& Nussenzweig, V. (1987) Science 238, 81-84.

Davitz, M. A., Hom, J., \& Schenkman, S. (1989) J. Biol. Chem. 264, 13760-13764.

DeCamilli, P., Moretti, M., Donini, S. D., Walter, U., \& Lohmann, S. (1986) J. Cell Biol. 103, 189-203.

Doering, T. L., Masterson, W. J., Hart, G. W., \& Englund, P. T. (1990) J. Biol. Chem. 265, 611-614.

Edelman, A. M., Blumenthal, D. K., \& Krebs, E. G. (1987) Annu. Rev. Biochem. 56, 567-613.

Ferguson, M. A. J., \& Cross, G. A. M. (1984) J. Biol. Chem. 259, 3011-3015.

Ferguson, M. A. J., Low, M. G., \& Cross, G. A. M. (1985) J. Biol. Chem. 260, 14547-14555.

Ferguson, R., \& Williams, A. F. (1988) Annu. Rev. Biochem. 57, 285-320.

Fersht, A. (1985) in Enzyme Structure and Mechanism, p 191, Freeman Publications, San Francisco.

Flockart, D. A., \& Corbin, J. D. (1982) CRC Crit. Rev. Biochem. 12, 133-186.

Gruber, W., Möllering, H., \& Bergmeyer, H. U. (1966) Enzymol. Biol. Clin. 7, 115-123.

Hixson, C. S., \& Krebs, E. G. (1980) J. Biol. Chem. 255, 2137-2145.

Ishihara, M., Fedarko, N. S., \& Conrad, H. E. (1987) J. Biol. Chem. 262, 4708-4716. 
Jaynes, P. K., McDonough, J. P., \& Mahler, H. R. (1980) Biochem. Biophys. Res. Commun. 94, 16-22.

Johnson, K. E., Cameron, S., Toda, T., Wigler, M., \& Zoller, M. J. (1987) J. Biol. Chem. 262, 8636-8642.

Kamps, M. P., Buss, J. E., \& Sefton, B. W. (1985) Proc. Natl. Acad. Sci. U.S.A. 82, 4625-4628.

Korc-Grodzicki, B., Tauber-Finkelstein, M., \& Shaltiel, S. (1988) Proc. Natl. Acad. Sci. U.S.A. 85, 7541-7545.

Kübler, D., Pyerin, W., Bill, O., Hotz, A., Sonka, J., \& Kinzel, V. (1989) J. Biol. Chem. 264, 14549-14555.

Kunisawa, R., Davis, T. N., Urdea, M. S., \& Thorner, J. (1987) Nucleic Acids Res. 15, 368-369.

Lang, B., Burger, G., \& Bandlow, W. (1974) Biochim. Biophys. Acta 368, 71-85.

Lohmann, S. M., \& Walter, U. (1984) Adv. Cyclic Nucleotide Protein Phosphorylation Res. 18, 63-117.

Lohmann, S. M., DeCamilli, P., Einig, I., \& Walter, U. (1984) Proc. Natl. Acad. Sci. U.S.A. 81, 6723-6727.

Low, M. G. (1987) Biochem. J. 244, 1-13.

Low, M. G. (1989) Biochim. Biophys. Acta 988, 427-454.

Matsumoto, K., Uno, I., Oshima, Y., \& Ishikawa, T., (1982a) Proc. Natl. Acad. Sci. U.S.A. 79, 2355-2359.

Matsumoto, K., Uno, I., Toh-e, A., Ishikawa, T., \& Oshima, Y. (1982b) J. Bacteriol. 150, 277-285.

Matsumoto, K., Uno, I., \& Ishikawa, T. (1983a) Cell 32, 417-423.

Matsumoto, K., Uno, I., \& Ishikawa, T. (1983b) Exp. Cell Res. 146, 151-161.

Matsumoto, K., Uno, I., \& Ishikawa, T. (1985) Yeast 1, 15-24.

Merino, A., Buckbinder, L., Mermelstein, F. H., \& Reinberg, D. (1989) J. Biol. Chem. 264, 21266-21276.

Mitts, M. R., Grant, D. B., \& Heideman, W. (1990) Mol. Cell. Biol. 10, 3873-3883.

Mostov, K. E., DeFoor, P., Fleischero, S., \& Blobel, G. (1981) Nature 292, 87-88.

Müller, G., \& Bandlow, W. (1987) Yeast 3, 161-170.

Müller, G., \& Bandlow, W. (1989a) Biochemistry 28, 9957-9967.

Müller, G., \& Bandlow, W. (1989b) Biochemistry 28, 9968-9973.
Müller, G., \& Bandlow, W. (1989c) Biochemistry 28, 9974-9981.

Nairn, A. C., Hemmings, H. C., \& Greengard, P. (1985) Annu. Rev. Biochem. 54, 931-976.

Nigam, S. K., \& Blobel, G. (1989) J. Biol. Chem. 264, 16927-16932.

Nigg, E. A., Hilz, H., Eppenberger, H. M., \& Dutley, F. (1985a) EMBO J. 4, 2802-2806.

Nigg, E. A., Schäfer, G., Hilz, H., \& Eppenberger, H. M. (1985b) Cell 41, 1039-1051.

Olson, S., \& Spitz, O. (1986) J. Biol. Chem. 261, 2458-2466.

Pall, G. (1981) Microbiol. Rev. 45, 462-480.

Rhee, T., \& Hunter, G. (1987) J. Virol. 31, 360-369.

Rödel, G., Müller, G., \& Bandlow, W. (1985) J. Bacteriol. $161,7-12$.

Sakar, D., Ehrlichman, J., \& Rubin, C. S. (1984) J. Biol. Chem. 259, 9840-9846.

Salomon, Y., Londos, C., \& Rodbell, M. (1974) Anal. Biochem. 58, 541-548.

Smith, M. E., Dickinson, J. R., \& Wheals, A. E. (1990) Yeast $6,53-60$.

Srere, P. A. (1965) Biochim. Biophys. Acta 106, 445-452.

Stieger, A., DeAlmeida, C. M. L., Blatter, M. C., Brodbeck, U., \& Bordier, C. (1986) FEBS Lett. 199, 182-186.

Takami, N., Ogata, S., Oda, K., Misumi, Y., \& Ikehara, Y. (1988) J. Biol. Chem. 263, 3016-3021.

Thorner, J. (1982) Cell 30, 5-6.

Toda, T., Cameron, S., Sass, P., Zoller, M., Scott, J. D., McMullen, B., Hurwitz, M., Krebs, E. G., \& Wigler, M. (1987) Mol. Cell. Biol. 7, 1371-1377.

Trams, E. G. (1974) Nature 252, 480-482.

Vai, M., Popolo, L., Grandori, R., Lacana, E., \& Alberghina, L. (1990) Biochim. Biophys. Acta 1038, 277-285.

Wen, T. C., Chang, C. M., Reitherman, R. W., \& Harding, B. W. (1985) Endocrinology 116, 935-944.

Wingender-Drissen, R. (1983) FEBS Lett. 163, 28-32.

Uno, I., Matsumoto, K., \& Ishikawa, T. (1982) J. Biol. Chem. $257,2355-2353$. 